\title{
PENGARUH KECEMASAN SAAT PEMBELAJARAN DARING MASA PANDEMI COVID-19 TERHADAP PRESTASI BELAJAR MAHASISWA STIKES WILLIAM SURABAYA
}

\author{
Erika Untari Dewi* \\ STIKes William Booth Surabaya. Jl. Cimanuk No.20 Surabaya 60241. \\ untarierika@yahoo.co.id
}

\begin{abstract}
ABSTRAK
Pembelajaran daring merupakan pembelajaran tanpa tatap muka secara langsung antara dosen dan mahasiswa. Dengan adanya pembelajaran daring seringkali membuat mahasiswa menjadi cemas. kecemasan adalah suatu keadaan aprehensi atau keadaan khawatir yang mengeluhkan bahwa yang buruk akan segera terjadi. Karena kuliah daring lebih banyak tugas dibandingkan dengan pengajaran mata kuliah dan juga dengan mengikuti perkuliahan daring bisa mendapatkan IPK yang kurang baik. Desain penelitian yang digunakan adalah korelasional, yang bertujuan untuk mencari hubungan antara pembelajaran daring dengan kecemasan mahasiswa. Variabel independen dalam penelitian ini yaitu pembelajaran daring dan variabel dependen yaitu kecemasan mahasiswa. Populasi pada penelitian ini yaitu mahasiswa Stikes William Booth berjumlah 19 responden, dengan sampel 19 responden. Pengumpulan data dengan kuisioner pembelajaran daring, kecemasan Hars dan data prestasi mahasiswa berupa indeks prestasi. Hasil penelitian menunjukan pembelajaran daring cukup sebanyak 14 orang $(73,6 \%)$ dan kecemasan Hars sedang sebanyak 9 orang (47,3\%) serta Indeks prestasi 3,00 - 3,49 sebanyak $52 \%$. Analisa data menggunakan uji statistic spearman Rho Correlation de peroleh tingkat kemaknaan 0,04 ( $\mathrm{p}<0,05)$. Dengan demikian Ho di tolak yang berarti ada hubungan kecemasan selama pembelajaran daring dengan prestasi mahasiswa mahasiswa di Stikes William Booth.
\end{abstract}

\section{Kata Kunci : Pembelajaran daring, kecemasan mahasiswa, prestasi mahasiswa}

\begin{abstract}
Online learning is direct learning without face to face between lecturers and students. Online learning often makes students worried. anxiety is a state of apprehension or a state of worry that complains that the bad will happen soon. Because online lectures have more assignments compared to teaching courses and also by attending online lectures can get poor GPA. The research design used is correlational, which aims to find the relationship between online learning and student anxiety. The independent variable in this study is online learning and the dependent variable is student anxiety. The population in this study were William Booth Stikes students totaling 19 respondents, with a sample of 19 respondents. Data collection with online learning questionnaires and Hars anxiety. The results showed enough online learning as many as 14 people (73.6\%) and moderate anxiety as many as 9 people (47.3\%) and an achievement index of 3.00 3.49 as much as 52. Data analysis using the Spearman Rho Correlation statistical test obtained a significance level of 0.04 ( $\mathrm{p}<0.05$ ). Thus Ho is accepted, which means that there is a relationship anxiety during online learning with student achievement at Stikes William Booth. Can see the existence of the results of this study can help to find out whether there is a relationship between online learning with student anxiety or not and the results obtained are no relationship between online learning and student anxiety at STIKES William Booth Surabaya.
\end{abstract}

Keywords : Online learning, student anxiety, student achievemen 


\section{PENDAHULUAN}

Pada awal tahun 2020, dunia digemparkan dengan merebaknya virus baru yaitu coronavirus jenis baru (SARS-CoV-2) dan penyakitnya disebut Corona virus disease 2019 (COVID-19). Diketahui, asal mula virus ini berasal dari Wuhan, Tiongkok, ditemukan pada akhir Desember tahun 2019. Sampai saat ini sudah dipastikan terdapat 65 negara yang telah terjangkit virus ini (data WHO, 1 maret 2020) (PDPI,2020). World Health Organization memberi nama virus baru tersebut Severe acute respiratory syndrome coronavirus-2 (SARS-CoV-2) dan nama penyakitnya sebagai Coronavirus disease 2019 (COVID-19) (WHO,2020). COVID-19 merupakan penyakit yang di identifikasi penyebabnya adalah virus corona yang menyerang sistem pernapasan. Akibat system penyebaran penyakit ini maka untuk menghindari penyebarannya semakin meluas saat ini system pengajaran di sekolah maupun di perguruan tingi dilakukan dengan system daring atau online. Pembelajaran daring merupakan pembelajaran tanpa tatap muka secara langsung antara dosen dan mahasiswa, tetapi melakukan melalui online. Pembelajarang dilakukan melalui video conference, e-learning atau distance learning. Pembelajaran daring merupakan hal yang baru, baik bagi mahasiswa maupun dosennya sehingga membutuhkan waktu yang cukup lama untuk beradaptasinya (hakiman,2020). Dampak positif dan negatif pada pembelajaran daring mahasiswa bisa mendapatkan materi dengan mudah dan belajar mengevaluasi pembelajaran sendiri dimanapun mereka berada, baik dirumah maupun di tempat umum lainnya sedangkan dampak negatifnya adalah banyaknya mahasiswa yang menyalahgunakan system belajar online, dan menggunakan waktu belajarnya ini dengan hal hal yang bisa dibiang kurang penting, dan itu bisa merugikan dirinya sendiri (Eko Putra 2020). Dampak akibat sistim pembelajaran ini adalah kecemasan mahasiswa dan ini bisa memnyebabkan terjadinya penurunan prestasi. Pembelajaran daring mahasiswa merasa cemas karena harus menyesuaikan kuliah daring ini dengan aplikasi - aplikasi yang sebelumnya pernah memakainya. Mereka merasa cemas karena dengan kuliah daring ini lebih banyak tugas dibandingkan dengan pengajaran mata kuliah, dan juga dengan pembelajaran daring ini apakah mereka bisa mendapatkan IPK dengan baik. Banyak faktor yang mempengaruhi prestasi belajar di antaranya adalah tujuan yang hendak di capai, situasi yang mempengaruhi, kesiapan mahasiswa untuk belajar, minat dan konsentrasi mahasiswa dalam belajar, waktu dan kesiapan belajar, karena banyaknya faktor-faktor yang berpengaruh dalam proses pendidikan. Faktor psikologis juga mempengaruhi motivasi belajar dan prestasi belajar seseorang. Beberapa faktor utama adalah kecerdasan siswa, minat, sikap, bakat dan percaya diri. Lingkungan belajar menurut Saroni, (2006) bahwa segala sesuatu yang berhubungan dengan tempat proses pembelajaran dilaksanakan, untuk fasilitas saranapun tampaknya sudah menjadi commitment para pendirinya sejak awal. Hal ini tampak misalnya dari ketersediaan fasilitas pembelajaran yang sangat memadai e- learning.

\section{METODE PENELITIAN}

Rancangan penelitian ini menggunakan deskriptif kolerasi yaitu penelitian yang bertujuan untuk mengungkapkan hubungan koleratif antar variabel. Pada penelitian ini untuk mengambil sampel dalam waktu yang bersamaan maka penulis menggunakan desain penelitian dengan cross sectional. Populasi penelitian ini adalah mahasiswa dengan pembelajaran daring yang mengalami kecemasan dengan jumlah populasi sebanyak 19 orang. Teknik sampling yang digunakan total sampling yaitu dengan mengambil seluruh jumlah populasi menjadi sampel. Variabel yang digunakan dalam penelitian ini adalah Variabel Independen yakni factor yang mempengaruhi prestasi yakni : kecemasan dan Variabel Dependen yakni 
prestasi mahasiswa. Instrumen yang digunakan dalam penelitian ini adalah kuisoner. Data diolah dan di analisa dengan menggunakan program SPSS 16.0 yang mengunakan uji statistic Wilcoxon.

\section{HASIL}

Tabel 1 Distribusi karakteristik responden berdasarkan jenis kelamin

\begin{tabular}{|c|c|c|}
\hline $\begin{array}{c}\text { Jenis } \\
\text { kelamin }\end{array}$ & Frekuensi & Persentase \\
\hline Laki - laki & 4 & $21 \%$ \\
\hline Perempuan & 15 & $78,9 \%$ \\
\hline Total & 19 & $100 \%$ \\
\hline
\end{tabular}

Tabel 2 Distribusi karakteristik responden berdasarkan usia

\begin{tabular}{|c|c|c|}
\hline Usia & Frekuensi & Prosentase \\
\hline $18-20$ tahun & 11 & $57,8 \%$ \\
\hline $21-23$ tahun & 8 & $42,1 \%$ \\
\hline Total & 19 & $100 \%$ \\
\hline
\end{tabular}

Tabel 3 Distribusi pendidikan orang tua responden

\begin{tabular}{|c|c|c|}
\hline Pendidikan & Frekuensi & Prosentase \\
\hline SD & 7 & $36,8 \%$ \\
\hline SMP & 1 & $5,2 \%$ \\
\hline SMA & 3 & $15,7 \%$ \\
\hline PT & 8 & $42,1 \%$ \\
\hline Total & 19 & $100 \%$ \\
\hline
\end{tabular}

Tabel 4 Distribusi responden berdasarkan tempat tinggal

\begin{tabular}{|c|c|c|}
\hline Tempat tinggal & Frekuensi & Prosentase \\
\hline Asrama & 8 & $42,1 \%$ \\
\hline Kost & 5 & $26,3 \%$ \\
\hline dengan orang tua & 6 & $31,5 \%$ \\
\hline Total & 19 & $100 \%$ \\
\hline
\end{tabular}

Tabel 5 Distribusi responden berdasarkan pekerjaan orang tua

\begin{tabular}{|c|c|c|}
\hline $\begin{array}{c}\text { Pekerjaan } \\
\text { orang tua }\end{array}$ & Frekuensi & Prosentase \\
\hline PNS & 7 & $36,8 \%$ \\
\hline Swasta & 1 & $52 \%$ \\
\hline Wiraswasta & 3 & $15,7 \%$ \\
\hline Lainnya & 8 & $42,1 \%$ \\
\hline Total & 19 & $100 \%$ \\
\hline \multicolumn{2}{|c}{} \\
\hline
\end{tabular}

Tabel 6 Distribusi responden berdasarkan dana pulsa per bulan

\begin{tabular}{|l|c|c|}
\hline $\begin{array}{c}\text { Dana pulsa per } \\
\text { bulan }\end{array}$ & Frekuensi & Prosentase \\
\hline Rp. 50.000 & 12 & $63,1 \%$ \\
\hline $\begin{array}{l}\text { Rp. } 50.000- \\
100.000\end{array}$ & 4 & $21, \%$ \\
\hline $\begin{array}{l}\text { Rp. } 100.000- \\
150.000\end{array}$ & 2 & $10,5 \%$ \\
\hline Rp.>150.000 & 1 & $5,2 \%$ \\
\hline Total & 19 & $100 \%$ \\
\hline
\end{tabular}

Tabel 7 Distribusi responden berdasarkan berapa bersaudara

\begin{tabular}{|c|c|c|}
\hline Jumlah bersaudara & Frekuensi & Prosentase \\
\hline Dua bersaudara & 5 & $26 \%$ \\
\hline Tiga bersaudara & 6 & $31 \%$ \\
\hline $\begin{array}{l}\text { Lebih dari tiga } \\
\text { bersaudara }\end{array}$ & 8 & $42 \%$ \\
\hline Total & 19 & $99 \%$ \\
\hline
\end{tabular}

Tabel 8 Kepemilikan laptop atau komputer

\begin{tabular}{|c|c|c|}
\hline Memiliki laptop & Frekuensi & Prosentase \\
\hline Ya & 15 & $78,9 \%$ \\
\hline Tidak & 4 & $21 \%$ \\
\hline Total & 19 & $100 \%$ \\
\hline
\end{tabular}

Tabel 9 Kondisi jaringan di tempat anda memadai

\begin{tabular}{|c|c|c|}
\hline Kondisi jaringan & Frekuensi & Prosentase \\
\hline Ya & 12 & $63,1 \%$ \\
\hline Tidak & 7 & $36,8 \%$ \\
\hline Total & 19 & $100 \%$ \\
\hline
\end{tabular}

Tabel 10 Pembelajaran daring lebih efektif

\begin{tabular}{|c|c|c|}
\hline $\begin{array}{l}\text { Pembelajaran } \\
\text { daring lebih } \\
\text { efektif }\end{array}$ & Frekuensi & Prosentase \\
\hline Ya & 6 & $31,1 \%$ \\
\hline Tidak & 13 & $68,4 \%$ \\
\hline Total & 19 & $100 \%$ \\
\hline
\end{tabular}


Tabel 11 kemampuan mencari berbagai sumber informasi di internet

\begin{tabular}{|c|c|c|}
\hline $\begin{array}{l}\text { Kemampuan } \\
\text { mencari berbagai } \\
\text { sumber informasi } \\
\text { di internet }\end{array}$ & Frekuensi & Prosentase \\
\hline Sangat mampu & 5 & $26,3 \%$ \\
\hline Mampu & 14 & $73,6 \%$ \\
\hline Kurang mampu & 0 & $0 \%$ \\
\hline Tidak mampu & 0 & $0 \%$ \\
\hline Total & 19 & $100 \%$ \\
\hline
\end{tabular}

Tabel 12 Kemampuan menggunakan berbagai aplikasi dalam komputer untuk menyelesaikan tugas.

\begin{tabular}{|c|c|c|}
\hline $\begin{array}{l}\text { Kemampuan } \\
\text { menggunakan } \\
\text { berbagai aplikasi }\end{array}$ & Frekuensi & Prosentase \\
\hline Sangat mampu & 6 & $31,5 \%$ \\
\hline Mampu & 10 & $52,6 \%$ \\
\hline Kurang mampu & 3 & $15,7 \%$ \\
\hline Tidak mampu & 0 & $0 \%$ \\
\hline Total & 19 & $100 \%$ \\
\hline
\end{tabular}

Tabel 13 Kecepatan memberi respon umpan/ umpan balik pada pembelajaran daring

\begin{tabular}{|c|c|c|}
\hline $\begin{array}{l}\text { Kecepatan } \\
\text { memberi respon }\end{array}$ & Frekuensi & Prosentase \\
\hline Sangat cepat & 0 & $0 \%$ \\
\hline Cepat & 4 & $21 \%$ \\
\hline Kurang cepat & 15 & $78,9 \%$ \\
\hline Tidak cepat & 0 & $0 \%$ \\
\hline Total & 19 & $100 \%$ \\
\hline
\end{tabular}

Tabel 14 Waktu pembelajaran daring bisa dilakukan kapan saja

\begin{tabular}{|c|c|c|}
\hline $\begin{array}{l}\text { Waktu } \\
\text { pembelajaran } \\
\text { daring }\end{array}$ & Frekuensi & Prosentase \\
\hline Sangat setuju & 3 & $15,7 \%$ \\
\hline Setuju & 8 & $42,1 \%$ \\
\hline Kurang setuju & 6 & $31,5 \%$ \\
\hline Tidak setuju & 2 & $10.5 \%$ \\
\hline Total & 19 & $100 \%$ \\
\hline
\end{tabular}

Tabel 15 Pembelajaran daring membuat proses pembelajaran lebih di mengerti

\begin{tabular}{|c|c|c|}
\hline $\begin{array}{l}\text { Pembelajaran daring } \\
\text { membuat proses } \\
\text { pembelajaran lebih } \\
\text { di mengerti }\end{array}$ & Frekuensi & Prosentase \\
\hline Sangat setuju & 1 & $5,2 \%$ \\
\hline Setuju & 2 & $10,5 \%$ \\
\hline Kurang setuju & 13 & $68,4 \%$ \\
\hline Tidak setuju & 4 & $21 \%$ \\
\hline Total & 19 & $100 \%$ \\
\hline
\end{tabular}

Tabel 16 Media pembelajaran daring lebih mudah di akses

\begin{tabular}{|c|c|c|}
\hline $\begin{array}{l}\text { Media pembelajaran } \\
\text { daring lebih mudah } \\
\text { di akses }\end{array}$ & Frekuensi & Prosentase \\
\hline Sangat setuju & 1 & $5,2 \%$ \\
\hline Setuju & 6 & $31,5 \%$ \\
\hline Kurang setuju & 11 & $57,8 \%$ \\
\hline Tidak setuju & 1 & $5,2 \%$ \\
\hline Total & 19 & $100 \%$ \\
\hline
\end{tabular}

Tabel 17 Pembelajaran daring memerlukan fasilitas yang memadai

\begin{tabular}{|c|c|c|}
\hline $\begin{array}{l}\text { Pembelajaran } \\
\text { daring perlu } \\
\text { fasilitas yang } \\
\text { memadai }\end{array}$ & Frekuensi & Prosentase \\
\hline Sangat setuju & 9 & $47,3 \%$ \\
\hline Setuju & 7 & $36,8 \%$ \\
\hline Kurang setuju & 1 & $5,2 \%$ \\
\hline Tidak setuju & 2 & $10,5 \%$ \\
\hline Total & 19 & $100 \%$ \\
\hline
\end{tabular}

Tabel 18 Tabel kecemasan mahasiswa menurut HARS

\begin{tabular}{|c|c|c|}
\hline $\begin{array}{c}\text { Kecemasan } \\
\text { mahasiswa }\end{array}$ & Frekuansi & Prosentase \\
\hline Ringan & 15 & $78,9 \%$ \\
\hline Sedang & 2 & $10,5 \%$ \\
\hline Berat & 2 & $10,5 \%$ \\
\hline Panik & 0 & $0 \%$ \\
\hline Total & 19 & $100 \%$ \\
\hline
\end{tabular}


Tabel 19 Prestasi mahasiswa

\begin{tabular}{|c|c|c|}
\hline $\begin{array}{c}\text { Prestasi } \\
\text { mahasiswa }\end{array}$ & Frekuensi & Prosentase \\
\hline $3,50-4,00$ & 4 & $21 \%$ \\
\hline $3.00-3.49$ & 10 & $52 \%$ \\
\hline $2.50-2,99$ & 6 & $32 \%$ \\
\hline$<2,50$ & 0 & \\
\hline Total & 19 & $100 \%$ \\
\hline
\end{tabular}

\section{PEMBAHASAN}

Menurut teori (Hakiman,2020) Pembelajaran daring merupakan pembelajaran tanpa tatap muka secara langsung antara dosen dan mahasiswa, tetapi melakukan melalui online. Pembelajaran dilakukan melalui video conference, e-learning atau distancelearning. Pembelajaran daring dilaksanakan selama 9 minggu dan harus menyelesaikan setiap modul pembelajaran yang sudah disusun oleh tim dari diktis maupun kemenristedikti. Pembelajaran daring merupakan hal yang baru, baik bagi mahasiswa maupun dosennya sehingga membutuhkan waktu yang cukup lama untuk beradaptasinya. sejak Mendikbud mengeluarkan Surat Edaran Nomor 36962/MPK.A/HK/2020 agar seluruh kegiatan belajar mengajar baik di sekolah maupun kampus perguruan tinggi menggunakan metode daring (dalam jaringan) alias online sebagai upaya pencegahan terhadap perkembangan dan penyebaran Coronavirus disease (Covid-19). Banyak sekali kisah menarik, lucu, maupun sedih yang terjadi dalam proses belajar dengan metode ini. Bisa dilihat bagaimana gagapnya para pendidik, stresnya orangtua yang mendampingi anak-anaknya belajar di rumah, dan tentunya bagaimana siswa kebingungan menghadapi tumpukan tugas yang aneh-aneh dari para pendidik yang sedang gagap.

Berdasarkan fakta dan teori dapat dijelaskan bahwa dana pulsa perbulan dari 19 responden terbanyak adalah Rp. 50.000 dengan 12 responden dan prosentase $(63,1 \%)$ dengan tempat tinggal, asrama sebanyak 8 responden dan prosentase 42,1\%, kost sebanyak 7 responden dengan prosenntase $36,8 \%$ dan tinggal dengan orang tua sebanyak 4 dengan prosentase $21 \%$. Sehingga dapat mendukung bahwa hasil pembelajaran daring yang paling banyak adalah cukup.

Berdasarkan tabel 5.9 menunjukan bahwa kecemasan mahasiswa dari 19 responden terbanyak adalah sedang dengan frekuensi 9 dan prosentase $47,3 \%$

Secara teori menurut (Nevid, 2010) kecemasan adalah suatu keadaan aprehensi atau keadaan khawatir yang mengeluhkan bahwa yang buruk akan segera terjadi. Kecemasan menjadi abnormal bila tingkatnya tidak sesuai dengan proporsi, ancaman atau bila sepertinya dating tanpa ada penyebabnya yaitu, bila bukan merupakan respon terhadap perubahan lingkungan. Kecemasan yang berlebihan dapat menyebabkan mahasiswa mengalami masalah psikosomatik. Gejala psikosomatik yang dapat dialami yaitu perasaan cemas, ketegangan, ketakutan, ketakutan, gangguan tidur, gangguan kecerdasan, perasaan depresi (murung), gejala somatik/fisik (otot), gejala somatik/fisik (sensorik), gejala kardiovaskuler, gejala pernapasan, gejala gastrointestinal (pencernaan), gejala urogenital, gejala autonom, dan gejala tingkah laku (sikap) (Hamilton dalam Mcdowell, 2006). Saat mengalami kecemasan sistem tubuh akan meningkatkan sistem kerja saraf simpatis sehingga menyebabkan perubahan pada respon tubuh (Patimah, Suryani, \& Nuraeni, 2015)

Berdasarkan data umum tempat tinggal responden, tidak terdapat hubungan kecemasan, akan tetapi tampak bahwa mahasiswa yang tinggal di asrama dan kos paling banyak mengalami kecemasan sedang. Mereka harus hidup terpisah dari orang tua, mereka harus menghadapi berbagai masalah 
sendiri tanpa bantuan orang tua. Kesamaan antara kecemasan mahasiswa karena dengan pembelajaran daring ini mahasiswa harus membutuhkan dana pulsa yang cukup sehingga pembelajaran daring ini dapat berjalan dengan baik tetapi peneliti melihat dari data umum responden dana pulsa perbulan adalah Rp. 50.000 dengan 12 responden dan prosentase $(63,1 \%)$. Kesimpulannya adalah dari dana pulsa yang kurang cukup responden akan berpikir apakah dengan dana pulsa yang kurang cukup responden dapat menjalankan perkuliahan dengan baik sehingga kecemasan mahasiswa yang paling banyak adalah tingkat sedang. Prestasi mahasiswa selama masa pembelajaran daring disebabkan karena pandemic Covid 19 paling banyak pada Indeks prestasi 3,00 - 3,49 sebanyak 52\% dan hal ini disebabkan karena mahasiswa masih pada tingkat kecemasan ringan yang paling banyak yakni 78,9 \%. Hal ini sesuai hasil uji statistic yaitu Dari hasil uji statistic spearman didapatkan nilai $\mathrm{p}=0,04$ dengan tingkat kemaknaan $\mathrm{p}<0,05$ yang berarti $\mathrm{HO}$ ditolak atau ada hubungan secara signifikan antara hubungan kecemasan dengan prestasi mahasiswa di Stikes William Booth Surabaya.

\section{DAFTAR PUSTAKA}

Depdiknas. (2008). KBBI Daring. Dipetik Februari 07, 2012, dari Pusat Bahasa

Khade, Alan S and Detelin Elenkov 2011. Learning An Oppoment's Strategy In cournot

Kapannee \& Rao, U. 2007, Test anxiety research in India. A review of research. Adv. Test Anx. Res., Netherlands,

Maurine, D.P. 1983. Relationships Between Self-Esteem, Anxiety, and Achievement in Young Learning Disabled Students. 16 (1); January 1983

McGinn, D. 1994. Kecemasan Ujian di Amerika. Majalah News Week edisi 6 September 1994.

Nursalam. (2013). Konsep dan penerapan metodologi penelitian ilmu keperawatan. Jakarta : Salemba Medika

Hakiman,2020. Pembelajaran daring pada mahasiswa. Eko Putra 2020. Dampak positif dan negative pada daring

Nevit, 2010 kecemasan, cervone,2012 gangguan kecemasan

Nevid Jeffrey S, Rathus Spencer A, dan Greene Beverly 2005 : 163 memberikan pengertian tentang kecemasan

WHO. Novel Coronavirus (2019-nCoV) Situation Report-1. Januari 21, 2020.

WHO. WHO Director-General's remarks at the media briefing on 2019-nCov on 11 February 2020. Cited Feb 13rd 2020. 